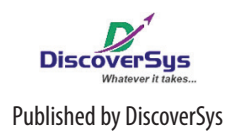

Published by DiscoverSys

\section{Engaging the private sector to improve antimicrobial use in the community}

\author{
Luh Putu Lila Wulandari, ${ }^{1,2^{*}}$ Virginia Wiseman ${ }^{1,3}$
}

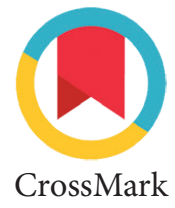

${ }^{1}$ The Kirby Institute, University of New South Wales,

${ }^{2}$ Department of Public Health and Preventive Medicine, Faculty of Medicine, Udayana University, ${ }^{3}$ London School of Hygiene \& Tropical Medicine
*Correspondence to: Luh Putu Lila Wulandari, The Kirby Institute, University of New South Wales, Department of Public Health and Preventive Medicine, Faculty of Medicine, Udayana University putuwulandari@gmail.com
Antimicrobial resistance (AMR) is one of the world's most pressing public health threats. It increases the cost of health care through longer duration of illness and hospital stays, ${ }^{1}$ additional tests, ${ }^{1}$ and the need for more expensive drugs. ${ }^{2}$ Around 700,000 people die of resistant infections every year globally. ${ }^{3}$ It has been projected that between now and 2050, AMR will result in around 10 million deaths with an associated economic cost, incurred by lost global production, of 100 trillion USD. ${ }^{3}$

AMR refers to the ability of a microorganism to stop an antimicrobial (such as an antibiotic, antiviral or antimalarial) from working against it. As a consequence of AMR, standard treatments become ineffective, and infections persist and may spread to others. The impact of AMR is far-reaching and equates to the situation before the discovery of antibiotics, when even small infections were difficult, or very often impossible to treat, and medical procedures too risky to perform due to the potential of untreatable infection.

According to the WHO, Southeast Asia is at the highest risk globally for the emergence and spread of AMR, predominantly due to the inappropriate use of antibiotics and weak systems of governance in health and agriculture. ${ }^{4,5}$ Excessive use of antibiotics for upper respiratory tract infections (URTI), where infection is commonly caused by a virus, is of particular concern in the region. ${ }^{6} \mathrm{~A}$ review by the WHO of studies published between 1990-2006 shows that between $40 \%-60 \%$ of viral URTI cases in South East Asian countries were treated with antibiotics, ${ }^{7}$ with the rate significantly higher in private facilities compared to public. ${ }^{7}$ Common drivers of inappropriate use of antibiotics include poor knowledge, perceived patient demand, economic incentives, pressure from pharmaceutical marketing, unstable drug supply, lack of regulation and enforcement, particular social and cultural norms around medicine use, and health seeking preferences. ${ }^{8-11}$

In 2011, health ministers in the Southeast Asian region adopted the Jaipur Declaration on AMR, calling for comprehensive action against the irrational use of antibiotics. ${ }^{12}$ Most recently, the Berlin declaration by G20 health ministers in May, 2017 recognised the increasing threat of AMR and outlined various measures to address it. ${ }^{13}$ The region's member states are currently implementing national action plans to tackle AMR. ${ }^{14}$ Indonesia’s National
Action Plan on Antimicrobial Resistance (NAP AMR) was shared at the WHO General Assembly in May, 2017. ${ }^{15}$ Key supply-side initiatives of NAP AMR include (i) regulation of the production and distribution of antibiotics (e.g. coordination with the drug regulatory authority to develop regulations and quality checklists for the import, manufacture, quality, distribution, market authorization, advertising, and inspection of antimicrobial agents; and the promotion of investment in developing new medicines, diagnostic tools, vaccines and other interventions); ${ }^{16,17}$ (ii) AMR control programmes in public hospitals (e.g. linking the AMR control activities with hospital accreditation systems and training healthcare workers and staff in infection prevention control procedures and guidelines; ${ }^{17,18}$ and (iii) hospital surveillance (e.g. scrutiny of antimicrobial prescribing, use, resistance, and monitoring hospital acquired infection). ${ }^{16,17}$ On the demand side, several awareness campaigns and training programmes have also been rolled out to improve knowledge about AMR among community groups, professional and government organisations, and journalists through platforms such as social media, workshops, and seminars. ${ }^{16,17,19}$ These various initiatives are still in their infancy and to our knowledge, their impact is yet to be comprehensively evaluated.

A recent systematic review of the impact of interventions to promote more effective use of antibiotics in low- and middle-income countries (LMICs) highlights the importance of improving the availability of diagnostic testing; providing dedicated education on AMR for both healthcare providers and the wider public; and strengthening (inter)national agencies responsible for the enforcement of regulations and auditing of the production, distribution and dispensing of antibiotics. ${ }^{20}$ Current evidence and policies for action on AMR focus heavily on the public sector. This is despite the fact that private drug sellerswhich typically include pharmacies, drug stores, general stores and itinerant vendors-are often the first point of contact and a major source of medicines and care in LMICs. ${ }^{21,22}$ For example, in Indonesia, $93 \%$ of patients are reported to obtain their antibiotics from these providers. ${ }^{23}$ Data from the Indonesian Ministry of Health shows that there are at least 26,658 licensed community pharmacies 
and 13,477 licensed drugstores across the country's 34 provinces..$^{24}$ In addition, there are at least 95,000 unlicensed outlets, consisting of 5,000 drug stores and 90,000 kiosks across the country. ${ }^{25}$ These private providers are often preferred because they are accessible, convenient and reliable sources of affordable medicines, ${ }^{26}$ but they also tend to be unregulated and staffed by largely untrained personnel..$^{21}$

The regulation and control of antibiotic use by private drug sellers is challenging. In Indonesia, antibiotics should only be dispensed by licensed pharmacists. Licenses for pharmacies are issued by the local district authority and involve submitting qualification and accreditation documents to the District Health Office (DHO), inspection of the facilities by the DHO and Food and Drug Administration (FDA) and subsequent processing of license applications by the DHO and FDA. In reality overall market control is weak ${ }^{25,27}$ with many unlicensed drug stores freely selling antibiotics. ${ }^{27-30}$ This situation is not unique to Indonesia with studies showing that antibiotics are widely available from unlicensed village grocers or drugstores in Thailand, Cambodia and Vietnam. ${ }^{31-33}$

Another regulation designed to encourage appropriate use of antibiotics by private drug sellers in Indonesia is the dispensing of prescriptiononly antibiotics. ${ }^{34}$ In Indonesia and many other LMICs, ${ }^{35}$ this regulation is poorly implemented and enforced. ${ }^{21,27,36-39}$ For example, it has been estimated that around $86 \%$ of Indonesians currently obtain antibiotics from private drug sellers without a prescription and without adequate information and history gathering. ${ }^{21,37,38}$ Concerns have also been raised in Indonesia about the repackaging of larger and often cheaper units of antibiotics without any label, ${ }^{27}$ and the dispensing of poor quality antibiotics by community pharmacies, shops and kiosks. ${ }^{27}$ Studies of private drug sellers in other LMICs have reported the dispensing of expired antibiotics ${ }^{40}$ and the provision of incomplete or shorter treatment courses, particularly in the case of patients who are thought to be too poor to afford a complete dose. ${ }^{40,41}$

The private sector has been an overlooked but major source of AMR in many LMICs, including Indonesia. Private drug sellers such as community pharmacies and drug stores therefore have a major part to play in educating patients, rationalising antibiotic use, and stopping antibiotic sales without a prescription. Drafting new laws and regulations to govern the private sector is, however, unlikely to provide a comprehensive solution to the problem of AMR. ${ }^{42}$ AMR research must be broadened to include the evaluation of multifaceted interventions that better reflect the complex incentives and preferences of private drug sellers and their clients. This evidence is urgently needed as countries like Indonesia finalise their National Action Plans and begin rolling out AMR related activities.

\section{REFERENCES}

1. Maragakis LL, Perencevich EN, Cosgrove SE. Clinical and economic burden of antimicrobial resistance. Expert Review of Anti-infective Therapy. 2008;6(5):751-63.

2. Hawkey PM. The growing burden of antimicrobial resistance. Journal of Antimicrobial Chemotherapy. 2008;62(suppl_1):i1-i9.

3. O'Neil J. Review on antimicrobial resistance. Tackling drug resistant infections globally: final report and recommendations.; 2016.

4. Chereau F, Opatowski L, Tourdjman M, Vong S. Risk assessment for antibiotic resistance in South East Asia. BMJ. 2017;358.

5. Holloway KA, Kotwani A, Batmanabane G, Puri M, Tisocki K. Antibiotic use in South East Asia and policies to promote appropriate use: reports from country situational analyses. BMJ. 2017;358.

6. Teng CL. Antibiotic prescribing for upper respiratory tract infections in the Asia-Pacific region: A brief review. Malaysian family physician : the official journal of the Academy of Family Physicians of Malaysia. 2014;9(2):18-25.

7. World Health Organization. Medicines use in primary care in developing and transitional countries Fact Book summarizing results from studies reported between 1990 and 2006. 2009.

8. McKay R, Mah A, Law MR, McGrail K, Patrick DM. Systematic Review of Factors Associated with Antibiotic Prescribing for Respiratory Tract Infections. Antimicrobial Agents and Chemotherapy. 2016;60(7):4106.

9. Radyowijati A, Haak H. Determinants of Antimicrobial Use in the Developing World. 2002.

10. Tangcharoensathien V, Chanvatik S, Sommanustweechai A. Complex determinants of inappropriate use of antibiotics. Bulletin of the World Health Organization. 2018;96(2):141-4.

11. Radyowijati A, Haak H. Improving antibiotic use in lowincome countries: an overview of evidence on determinants. Social Science \& Medicine. 2003;57(4):733-44.

12. World Health Organization Regional Office for South-East Asia. Jaipur declaration on antimicrobial resistance. . 2011.

13. G20 Health Ministers. Berlin Declaration of the G20 Health Ministers: Together Today for a Healthy Tomorrow. Germany2017.

14. Dr Poonam Khetrapal Singh. Speech of the Regional Director: Workshop on National Action Plan on Antimicrobial Resistance for Developing Countries: Focusing on Resistance Emanating from Antibiotic Use in Food Animals. New Delhi, India: 34th session of WHO South-East Asia Advisory Committee on Health Research, World Health Organization 2016.

15. Parathon H, Kuntaman K, Widiastoety TH, Muliawan BT, Karuniawati A, Qibtiyah M, et al. Progress towards antimicrobial resistance containment and control in Indonesia. BMJ. 2017;358.

16. Yuliati D. Guidelines on Implementation of Antimicrobial Resistance Program in Indonesia (Landasan Pelaksanaan Program Pengendalian Resistensi Antimikroba di Indonesia). Simposium Nasional Upaya Peningkatan Kesadaran Pencegahan Penyakit dan Penggunaan Antimikroba yang Baik dan Benar :"More Protection, Less Antimicrobial"; Jakarta2018.

17. The Indonesian Ministry of Health. National Action Plan Antimicrobial Resistance Indonesia 2017-2019. 2017. 
18. Indonesian Ministry of Health. Ministry of Health Regulation number 82015 Regarding Antimicrobial Resistant Control at Hospital Settings. 2015.

19. Indonesian Ministry of Health. Gema Cermat 2017 [Available from: http://farmalkes.kemkes.go.id/category/ gemacermat/\#.XAo5rNszb3g.

20. Cox JA, Vlieghe E, Mendelson M, Wertheim H, Ndegwa L, Villegas MV, et al. Antibiotic stewardship in low- and middle-income countries: the same but different? Clinical Microbiology and Infection. 2017;23(11):812-8.

21. Chee G, Borowitz M, Barraclough A. Private Health Care Sector in Indonesia. Bethesda, MD: Abt Associates Inc; 2009.

22. The Indonesian Ministry of Health. Riset Kesehatan Dasar (Riskesdas) 2013. 2013.

23. World Health Organization. Antibiotic Resistance: Multicounty Public Awareness Survey. 2015.

24. Indonesian Ministry of Health. Mapping of Pharmaceutical Facilities 2013 - 2016 (Aplikasi Pemetaan Sarana Kefarmasian 2013-2016) Jakarta 2017 [Available from: http://apif.binfar.depkes.go.id/index. php?req=view_services\&p=pemetaanIndustriFarmasi.

25. World Bank. Pharmaceuticals : why reform is needed (English). Indonesia health sector review : policy and discussion notes. Washington, DC: World Bank; 2009.

26. Goodman C, Kachur SP, Abdulla S, Bloland P, Mills A. Drug shop regulation and malaria treatment in Tanzaniawhy do shops break the rules, and does it matter? Health policy and planning. 2007;22(6):393-403.

27. Hadi U, van den Broek P, Kolopaking EP, Zairina N, Gardjito W, Gyssens IC. Cross-sectional study of availability and pharmaceutical quality of antibiotics requested with or without prescription (Over The Counter) in Surabaya, Indonesia. BMC infectious diseases. 2010;10:203.

28. Editor Kompas. Jual Obat Tanpa Resep, Tiga Pemilik Toko Obat Ditangkap. Kompas. 2009.

29. Amaluddin. Dinkes akan Datangi Apotek Jual Bebas Antibiotik. Metrotvnews. 2015.

30. Baskoro D. Waspada Resistensi Antibiotik, Ketahui Fungsinya Sebelum Dikonsumsi. Okezone. 2016.

31. Arparsrithongsagul S, Kulsomboon V, Zuckerman IH. Multidisciplinary Perspective Intervention With Community Involvement to Decrease Antibiotic Sales in Village Groceries in Thailand. Asia Pacific Journal of Public Health. 2015;27(2):NP2480-NP8.

32. Om C, Daily F, Vlieghe E, McLaughlin JC, McLaws M-L. Pervasive antibiotic misuse in the Cambodian community: antibiotic-seeking behaviour with unrestricted access. Antimicrobial resistance and infection control. 2017;6:30-.

33. Okumura J, Wakai S, Umenai T. Drug utilisation and self-medication in rural communities in Vietnam. Social Science \& Medicine. 2002;54(12):1875-86.
34. Presiden Republik Indonesia. Peraturan Pemerintah Republik Indonesia Nomor 51 Tahun 2009 tentang pekerjaan kefarmasian. Jakarta2009.

35. Sakeena MHF, Bennett AA, McLachlan AJ. Nonprescription sales of antimicrobial agents at community pharmacies in developing countries: a systematic review. International Journal of Antimicrobial Agents. 2018;52(6):771-82.

36. The Indonesian Ministry of Health. 86,10\% masyarakat di Indonesia mendapatkan antibiotik tanpa resep dokter 2018 [Available from: https://twitter.com/KemenkesRI/ status/1075669370 733350914.

37. Puspitasari HP, Faturrohmah A, Hermansyah A. Do Indonesian community pharmacy workers respond to antibiotics requests appropriately? Tropical medicine \& international health : TM \& IH. 2011;16(7):840-6.

38. Brata C, Marjadi B, Schneider CR, Murray K, Clifford RM. Information-gathering for self-medication via Eastern Indonesian community pharmacies: a cross-sectional study. BMC Health Serv Res. 2015;15:8.

39. Kotwani A, Wattal C, Joshi PC, Holloway K. Irrational use of antibiotics and role of the pharmacist: an insight from a qualitative study in New Delhi, India. Journal of Clinical Pharmacy and Therapeutics. 2012;37(3):308-12.

40. Kotwani A, Wattal C, Joshi PC, Holloway K. Irrational use of antibiotics and role of the pharmacist: an insight from a qualitative study in New Delhi, India. J Clin Pharm Ther. 2012;37(3):308-12.

41. Barker AK, Brown K, Ahsan M, Sengupta S, Safdar N. What drives inappropriate antibiotic dispensing? A mixedmethods study of pharmacy employee perspectives in Haryana, India. BMJ open. 2017;7(3).

42. Asharina I. Resistensi Antibiotic di Indonesia - Tak Usah Dulu Bermain Undang Undang. Bandung Institute of Technology 2016.

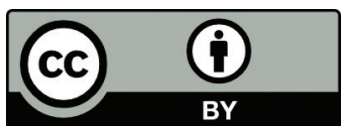

This work is licensed under a Creative Commons Attribution 